\title{
Gas Turbine Performances Improvement using Steam Injection in the Combustion Chamber under Sahara Conditions
}

\author{
A. Bouam 1 , S. Aïssani ${ }^{2}$ and R. Kadi ${ }^{1}$ \\ 1 Nuclear Research Center of Birine CRNB, PO Box 180, Aïn-Oussera 17200, Dielfa - Algeria \\ 2 Faculty of Hydrocarbons and Chemistry, University M'Hamed Bougara Boumerdes, Street of Independence - Boumerdes, 35000 - Algeria \\ e-mail: Bouam05_abd@yahoo.fr -Slim50dz@yahoo.fr - khaled2003@hotmail.com
}

Résumé - Amélioration des performances des turbines à gaz utilisées dans les conditions sahariennes par injection de vapeur d'eau - Le rôle des turbines à gaz, dans la production d'électricité et l'industrie pétrolière, a pris une dimension particulière ces dernières années. À cet effet différentes méthodes (régénération, refroidissement intermédiaire, préchauffage et injection de vapeur d'eau) ont été utilisées afin d'améliorer les performances des cycles de turbine à gaz. Dans cette optique, la méthode d'injection de vapeur d'eau en amont de la chambre de combustion d'une turbine à gaz a été proposée, étudiée et comparée avec un cycle simple. L'objectif principal de ce travail consiste en l'élaboration d'un programme de calcul de l'influence des conditions ambiantes sur les caractéristiques des différents processus de la turbine à gaz, telles que la compression, la combustion et la détente. Une fois les paramètres de fonctionnement optimaux connus, le calcul des performances de l'installation a été revu en injectant des quantités convenables de vapeur d'eau en amont de la chambre de combustion. Les résultats obtenus sont en accord avec ceux de la littérature et montrent que la méthode d'injection de vapeur d'eau en amont de la chambre de combustion améliore considérablement les performances de la turbine à gaz. Ces résultats sont représentés sous forme de courbes en deux et trois dimensions pour une meilleure illustration des phénomènes physiques.

\footnotetext{
Abstract - Gas Turbine Performances Improvement using Steam Injection in the Combustion Chamber under Sahara Conditions - Gas turbines are generally used for large scale power generation. The basic gas turbine cycle has low thermal efficiency which decreases in the hard climatic conditions of operation, so it is important to look for improved gas turbine based cycles. Among several methods shown their success in increasing the performances, the steam injected gas turbine cycle (STIG) consists to introduce a high amount of steam at various points in the cycle. The objective of the present work is to improve the performances of gas turbine used under Sahara conditions by injecting suitable quantities of steam in the upstream of combustion chamber. The suggested method has been studied and compared with a simple cycle. Efficiency, however, is held constant when the ambient temperature increases from iso conditions to $50^{\circ} \mathrm{C}$. Computer program has been developed for various gas turbine processes including the effect of ambient temperature. This is achieved by studying the effect of steam injection on the gas turbine performances. Data from the performance testing of an industrial gas turbine, computer model and theoretical study are used to check the validity of the proposed model. The comparison of the prediction results to the test data is in good agreement.
} 


\section{NOMENCLATURE}

$C_{f} \quad$ Flow coefficient, (-)

$c_{p}, c_{v} \quad$ Specific heats at constant pressure and volume, $(\mathrm{J} /(\mathrm{kg} . \mathrm{K}))$

$\bar{c}_{p} \quad$ Average specific heat at constant pressure, $(\mathrm{J} /(\mathrm{kg} . \mathrm{K}))$

$f \quad$ Fuel to air ratio (without injection of steam water)

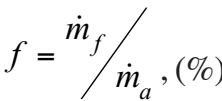

$f^{\prime} \quad$ Fuel to air ratio (with steam water injection)

$$
f^{\prime}=\dot{m}_{f}^{\prime} / \dot{m}_{a},(\%)
$$

GN Natural gas, (-)

$h \quad$ Specific enthalpy, $(\mathrm{J} / \mathrm{kg})$

$h_{f}^{o} \quad$ Standard specific enthalpy, $(\mathrm{J} / \mathrm{kg})$

$k \quad$ Polytropic coefficient of the fluid, (-)

$L C V \quad$ Lower calorific value of the fuel, $(\mathrm{kJ} / \mathrm{kg})$

$M \quad$ Molecular mass, $(\mathrm{kg} / \mathrm{kmol})$

$\dot{m} \quad$ Mass rate of flow, $(\mathrm{kg} / \mathrm{s})$

$n_{i} \quad$ Fraction of an element in a gas mixture, (-)

$p \quad$ Pressure, (bar)

$P \quad$ Power, $(\mathrm{W})$

$P_{C} \quad$ Absorbed power by the compressor, (W)

$P_{T} \quad$ Power produced by the turbine, (W)

$R \quad$ Specific constant of gas, $(\mathrm{J} /(\mathrm{kg} . \mathrm{K}))$

$t \quad$ Temperature in, $\left({ }^{\circ} \mathrm{C}\right)$

$T \quad$ Temperature in, $(\mathrm{K})$

$T_{2}$ Isentropic temperature on the outlet side of the compressor, (K)

$T_{4} \quad$ Isentropic temperature on the outlet side of the turbine, $(\mathrm{K})$

\section{Greek}

$\lambda \quad$ Excess coefficient of air, (-)

$\Delta p \quad$ Drop of pressure, (bar)

$\eta_{C} \quad$ Isentropic efficiency of the compressor, (\%)

$\eta_{C C} \quad$ Combustion efficiency, $(\%)$

$\eta_{G} \quad$ Electric generator efficiency, (\%)

$\eta_{\text {mec }} \quad$ Mechanical efficiency, $(\%)$

$\eta_{T} \quad$ Isentropic output of turbine, (\%)

$\eta_{T h} \quad$ Thermal efficiency of the cycle, (\%)

$\varepsilon \quad$ Compressor pressure ratio, $\varepsilon=p_{2} / p_{1},(-)$

\section{Subscripts and superscripts}

1, 2, 3, 4 Positions of the cycle presented by the various elements of the gas turbine

a Air

Adm Admission

Amb Ambient

C Compressor

CC Combustion chamber

manf Manufacturer

f Fuel

g Combustion gases

inj Parameters of injection

Iso Standard conditions

P Power plant

s Steam water

$\mathrm{T} \quad$ Turbine

Ut Net power output

\section{INTRODUCTION}

The use of gas turbines is increasing for producing electricity, operating airplanes and for various industrial applications such as, nuclear power plant (NPP), and the petroleum power plant. In the last three decades, improvements in gas turbines have shown their success in increasing the amount of energy output from power stations [1-3]. The basic gas turbine cycle has low thermal efficiency which decreases in the hard climatic conditions of operation, so it is important to look for improved gas turbine based cycles. The gas turbine's performance is highly dependent on ambient temperature which varies considerably between the day and the night, the summer and the winter. The power that it yields, in particular, decreases considerably as ambient temperature increases. Industrial gas turbines are one of the well established technologies for power generation. Various additional cycle configurations such as reheating, regeneration, intercooling and steam injection have been suggested $[2,3]$. All of them offer increased performance and increased output compared to a dry gas turbine cycle. Several types of water or steam injection gas turbine cycle (STIG) have been proposed in previous studies and the performance characteristics of them investigated [1, 4-14]. The exhaust gas from the turbine is used as an energy source in a heat recovery steam generator (HRSG) where energy is transferred from the exhaust gases to the boiler feed water. The high pressure steam is generated from HRSG. The steam is then injected into the combustor. Injection of steam increases the mass flow rate through the expander and so the power output and the efficiency of the turbine increase. Steam injection also helps in reducing the NOx emissions from the gas turbine [15-19]. The amount of steam generated in the HRSG 


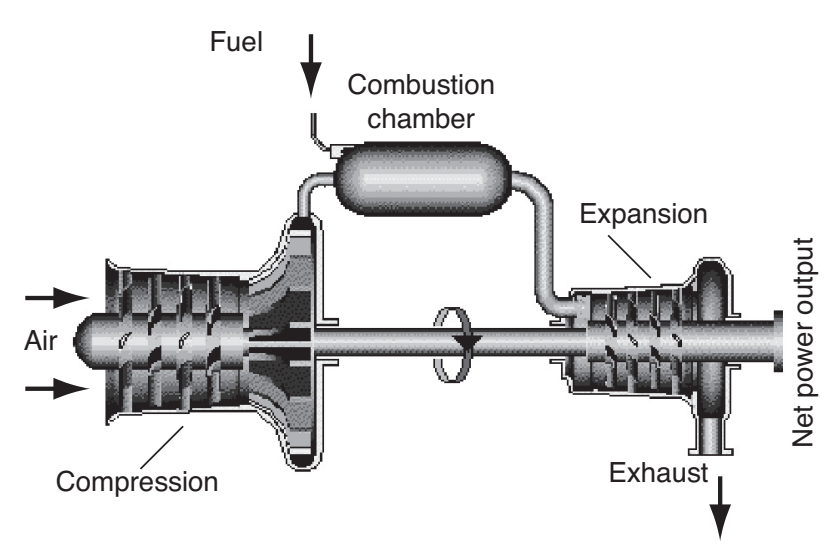

Figure 1

Illustrative diagram.

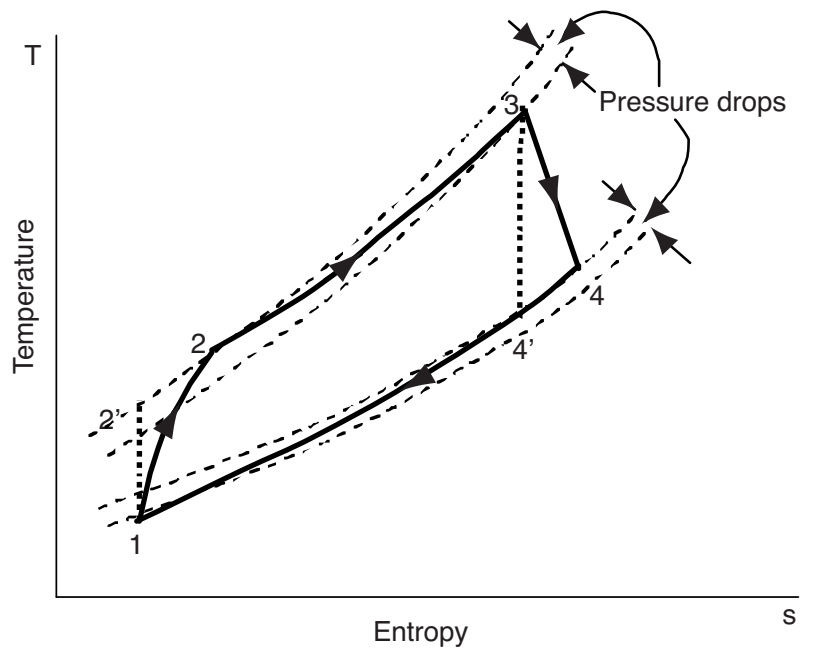

Figure 2

Thermodynamic cycles T-s of a simple gas turbine. depends upon the pinch point of the boiler. Due to this pinch point and the turbine outlet temperature, the HRSG cannot utilize all the heat available in the flue gas to generate steam.

The objective of the present work is to improve the performances of gas turbine used under Sahara conditions by injecting suitable quantities of steam in the upstream combustion chamber. The suggested method has been studied and compared with a simple cycle. Efficiency, however, is held constant when the ambient temperature increases from ISO conditions $\left(15^{\circ} \mathrm{C}, 60 \%\right.$ relative humidity) to $50^{\circ} \mathrm{C}$. Computer program has been developed for various gas turbine processes including the effect of ambient temperature. This is achieved by studying the effect of steam injection on the gas turbine performances.

\section{THERMODYNAMIC ANALYSIS}

\subsection{General Description}

The simple open cycle gas turbine with one shaft and the T-s diagram for this cycle are shown schematically in Figures 1, $2[1-3,20]$.

The non-ideal cycle (with fluid friction) is represented on T-s diagram by 1-2-3-4 and it can be characterized by two significant parameters: the pressure ratio and the combustion temperature. Both the compression process with fluid friction 1-2 and the expansion process with fluid friction 3-4 show an increase in entropy as compared with the corresponding ideal process 1-2' and 3-4'. Loss of pressure during heat addition (process 2-3) and heat rejection (process 4-1) are not neglected in this analysis. The compression and expansion process with fluid friction can be assigned polytropic or isentropic efficiencies $[2,3,20]$.

\subsection{Proposed Cycle}

The proposed scheme is based on a HRSG to a baseline combustion chamber.

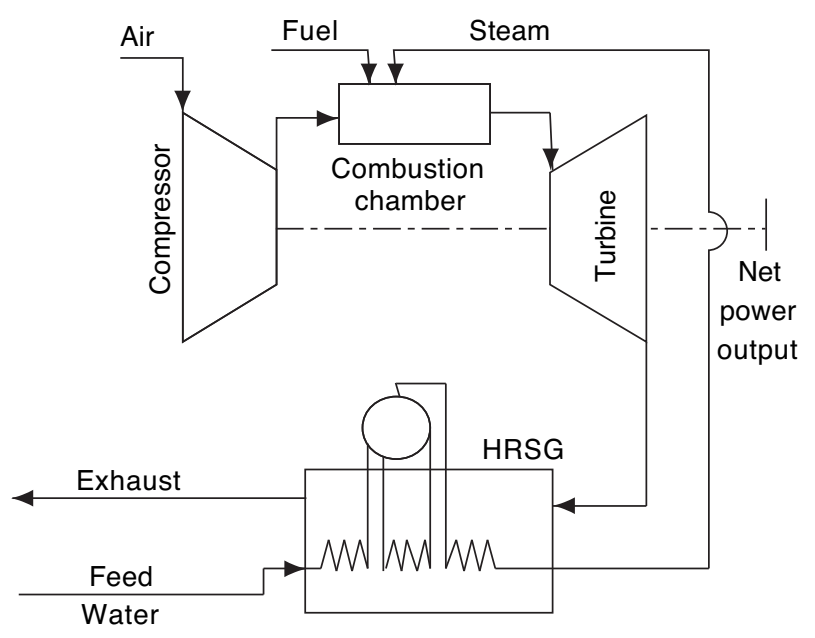

Figure 3

Scheme of the steam injected plant proposed. 
In this way, the original turbine is transformed into a STIG, thereby increasing power. Obviously only a limited amount of steam can be injected into the original gas turbine $[1,13,14,17]$. The calculations that follow are done considering a maximum of $10 \%$. The exhaust flow the existing HRSG is increased, those benefiting the steam cycle [1]. The pressure required to inject this steam into the turbine is relatively low compared to that usually employed in steam turbines. So the HRSG can be a very simple design, with a simple pressure level and a low pinch point, thus reducing the stuck temperature and increasing heat recovery. The proposed scheme is shown in Figure 3.

\subsection{Compression Analysis}

The work required to compress the unit mass of air in the compressor is then represented as:

$$
w_{C}=\frac{\int_{T_{1}}^{T_{2}} \bar{c}_{p a} \cdot d T}{M_{a}}
$$

\subsection{Combustion Chamber Analysis}

Concerning the combustor the computer code calculates the thermodynamics properties of the combustion products chemical and thermodynamic equilibrium. The hydrocarbons fuel chemical reaction is determine by the following expression, [1]:

$$
\begin{aligned}
& \mathrm{C}_{n} \mathrm{H}_{m}+\lambda\left(\frac{n+m}{4}\right)\left[\mathrm{O}_{2}+3.76 \mathrm{~N}_{2}\right]+(s) \mathrm{H}_{2} \mathrm{O} \rightarrow(n) \mathrm{CO}_{2} \\
& +\left[(\lambda-1)\left(n+\frac{m}{4}\right)\right] \mathrm{O}_{2}+\left[3.76 \lambda\left(\frac{n+m}{4}\right)\right] \mathrm{N}_{2}+(m / 2+s) \mathrm{H}_{2} \mathrm{O}
\end{aligned}
$$

\subsection{Expansion Analysis}

The specific work generated by the turbine per unit mass of air after receiving combustion gas of mass $(1+f)$, can be written as:

$$
w_{T}=\frac{\int_{T_{3}}^{T_{4}} \bar{c}_{p g} \cdot d T}{M_{g}}
$$

\section{PERFORMANCE ANALYSIS OF STIG CYCLES PLANT}

The analysis discuss in the previously paragraph concerns simple gas turbine cycle i.e. without steam injection. Furthermore, the approach followed has as a purpose the evaluation of overall performance changes by injecting the steam produced by the additional HRSG into the upstream of the combustor. The change in the parameters when steam is injected can be evaluated by applying the steady flow energy equation to the combustion chamber for operation without and with injection $[1,20]$. The follows into and out of a combustion chamber are shown schematically in Figure 4.

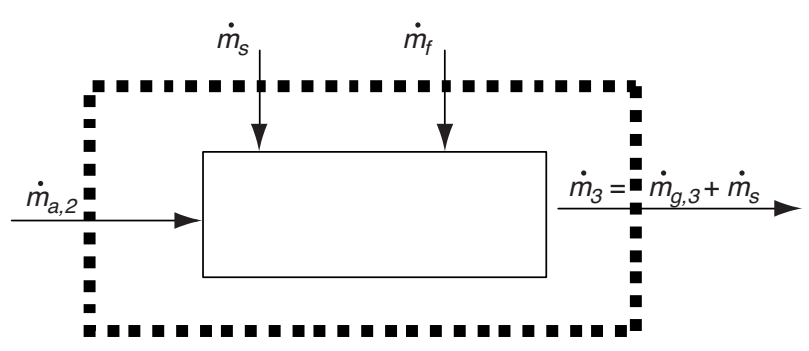

Figure 4

Control volume for application of the SFEE over the combustion chamber.

The SFEE (steady flow energy equation) for the combustion chamber is:

$$
\begin{gathered}
\dot{m}_{a}^{*} h_{2, a}+\dot{m}_{f} * L C V+\dot{m}_{s} * h_{s, t_{i n j}}= \\
\left(\dot{m}_{a}+\dot{m}_{f}\right) * h_{3, g}+\dot{m}_{s} * h_{s, t_{C C}}
\end{gathered}
$$

Writing this equation for dry and wet operation, gives the following relation for fuel-to-air ratio:

$$
\begin{gathered}
f=\frac{\dot{m}_{f}}{\dot{m}_{a}} \\
f^{\prime}=\frac{\left(h_{3, g}-h_{2, a}\right)+s\left(h_{3, s}-h_{2, s}\right)}{\eta_{C C} * C V-h_{3, g}}
\end{gathered}
$$

where

$$
\dot{m}_{f}=\frac{P_{\operatorname{manf}}}{L C V^{*} \eta_{\text {manf }}}
$$

We note that $s$ expresses the relative specific enthalpy raise of the injected steam with respect to the enthalpy rise for transformation of the air into combustion chamber. This parameter is then defined as:

$$
s=\frac{\left(A_{1}-C_{1}\right) * \alpha+\left(B_{1}-C_{1}\right) * \gamma}{\gamma * D_{1}-\left(A_{1}-C_{1}\right) * \beta}
$$


where:

$$
\left\{\begin{array}{l}
\alpha=h_{3, g}-h_{2, a} \\
\beta=h_{3, s}-h_{2, s} \\
\gamma=\eta_{C C} * L C V-h_{3, g} \\
A_{1}=\left(\eta_{T h e} * L C V\right) / \eta_{m e c} \\
B_{1}=w_{C} / \eta_{m e c} \\
C_{1}=h_{3, g}-h_{4, g} \\
D_{1}=h_{3, s}-h_{4, s}
\end{array}\right.
$$

The deviation of power output is summarized here for completeness. Power output is expressed by relating the net output to the difference between the turbine and compressor power:

$$
\begin{aligned}
P_{U t}= & \left(\dot{m}_{a}+\dot{m}_{f}\right) *\left(h_{3, g}-h_{4, g}\right) \\
& +\dot{m}_{s} *\left(h_{s, t_{c c}}-h_{s, t_{4}}\right)-\dot{m}_{a} *\left(h_{a, t_{2}}-h_{a, t_{1}}\right)
\end{aligned}
$$

The overall efficiency of plant is:

$$
\eta_{P}=\frac{P_{U t}}{\dot{m}_{f}^{\prime}{ }^{*} L C V}
$$

The scheme of the proposal analysis out lined above has been numerically studied using simulation computer program already by the authors. The computer program is based on fundamental thermodynamic relations including real gas behavior and the pressure losses [21-23].

\section{TEST DATA}

The validity of the relations presented above and their applicability to estimate the effect of steam injection will be assessed by application to test data from an operating industrial gas turbine. The tests are performed on a single shaft gas turbine (GE MS5002) [24]. Table 1 gives manufactures data,

\begin{tabular}{|c|c|c|c|c|c|c|c|}
\hline & $\begin{array}{c}\eta_{C} \\
(\%)\end{array}$ & $\begin{array}{c}\eta_{T} \\
(\%)\end{array}$ & $\begin{array}{l}\eta_{\text {mec }} \\
(\%)\end{array}$ & $\begin{array}{l}\Delta p_{c c} \\
(\%)\end{array}$ & $\begin{array}{l}\eta_{C C} \\
(\%)\end{array}$ & $\Delta p_{A d m}$ & 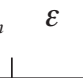 \\
\hline \multirow[t]{2}{*}{$\begin{array}{l}\text { Caractéristiques } \\
\text { of GE MS5002 }\end{array}$} & 90 & 88 & 95 & 4 & 95 & 1 & 7.376 \\
\hline & $\begin{array}{l}P_{\text {manf }} \\
(\mathrm{kW})\end{array}$ & $\begin{array}{c}\eta_{\text {Thmanf }} \\
(\%)\end{array}$ & $\begin{array}{l}t_{C C} \\
\left({ }^{\circ} \mathrm{C}\right)\end{array}$ & \multicolumn{2}{|c|}{$\begin{array}{c}L C V(\mathrm{GN}) \\
(\mathrm{kj} / \mathrm{kg})\end{array}$} & \multicolumn{2}{|c|}{$\oint_{f}$} \\
\hline $\begin{array}{l}\text { Caractéristiques } \\
\text { of GE MS5002 }\end{array}$ & 18000 & 23 & 900 & \multicolumn{2}{|c|}{45119} & \multirow{2}{*}{\multicolumn{2}{|c|}{${ }^{1.02} \mathbf{4}$}} \\
\hline RE & SULTS & AND II & JTERF & RETAT & IONS & & \\
\hline
\end{tabular}
at ISO conditions.

TABLE 1

Characteristics of the GE MS5002 gas turbine such as the compressor, combustor and the turbine are carried out with the aid of developed computer program. In this section we will discuss the effect of the major parameters (i.e. ambient temperature, pressure ratio, thermal efficiency...). The values of these parameters can be estimated using basic cycle equations given above and assuming variable values for thermodynamic proprieties. All the required readings were taken from the gas turbine model.

In the first case, the STIG cycle performance calculated over wide ranges of temperature $\left(0-50^{\circ} \mathrm{C}\right)$ and pressure ratio: (1-10) is optimized at standard ambient conditions. In the other hand, these optimal parameters are stabilized by injecting suitable amount of steam in the upstream of combustion chamber when the ambient temperature becomes higher ISO conditions.

\subsection{Simple Gas Turbine Performances Analysis Without Steam Injection}

For wide values of inlet temperature, the specific work of the compressor can be plotted against pressure ratio as shown in Figure 5.

It can be derived from this figure, that the specific work increases as the pressure ratio increase for a given inlet temperature. As for the effect of ambient temperature, the same variation is obtained. This is because, to compress the air at a higher temperature, the compressor needs a more significant work.

The efficiency observed decreases as ambient temperature is increased. This can be explained by Figure 6, which indicates the influence of ambient temperature on the variation of efficiency as a function of pressure ratio. For high inlet temperature $\left(t_{a m b}>30^{\circ} \mathrm{C}\right)$, efficiency reaches a maximum at

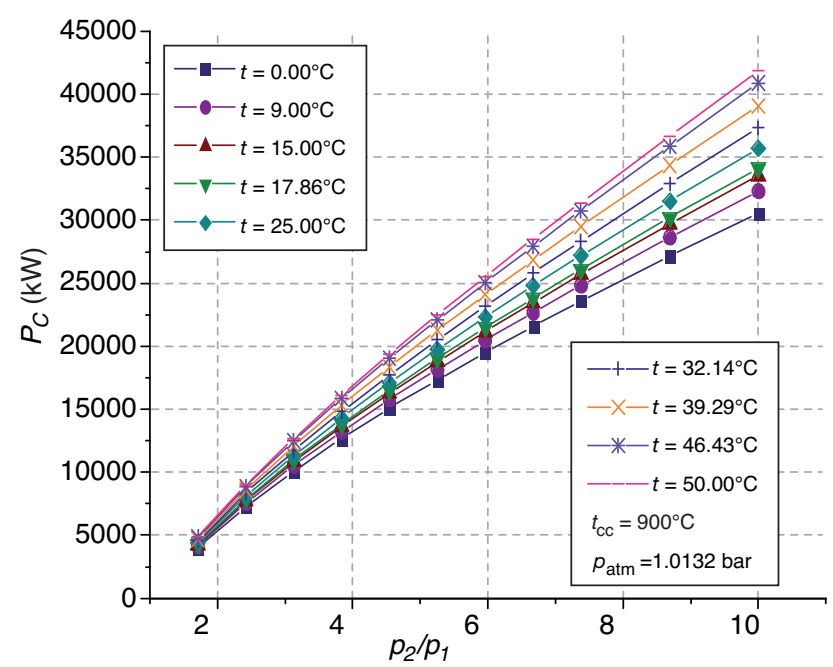

Figure 5

Specific work of compressor. 


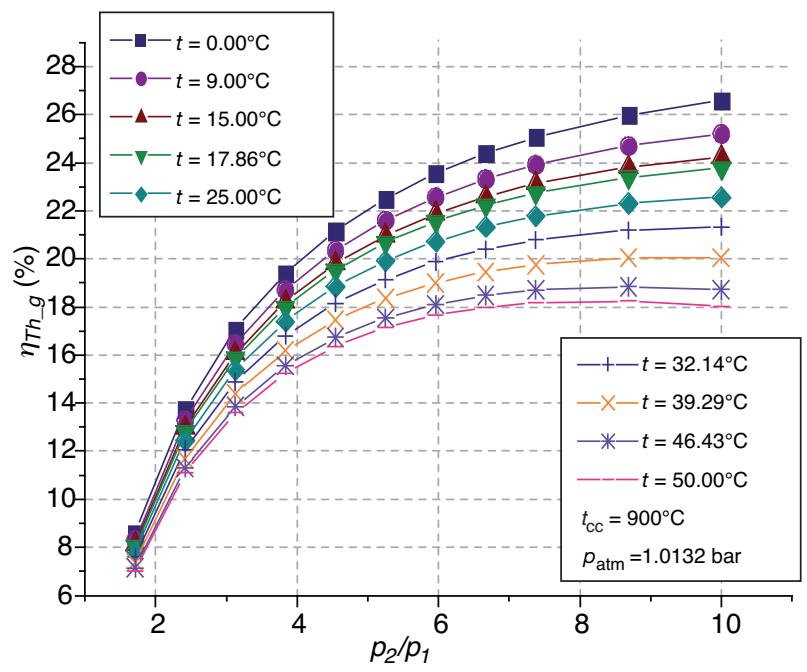

Figure 6

Thermal efficiency $v$ pressure ratio at different temperatures.

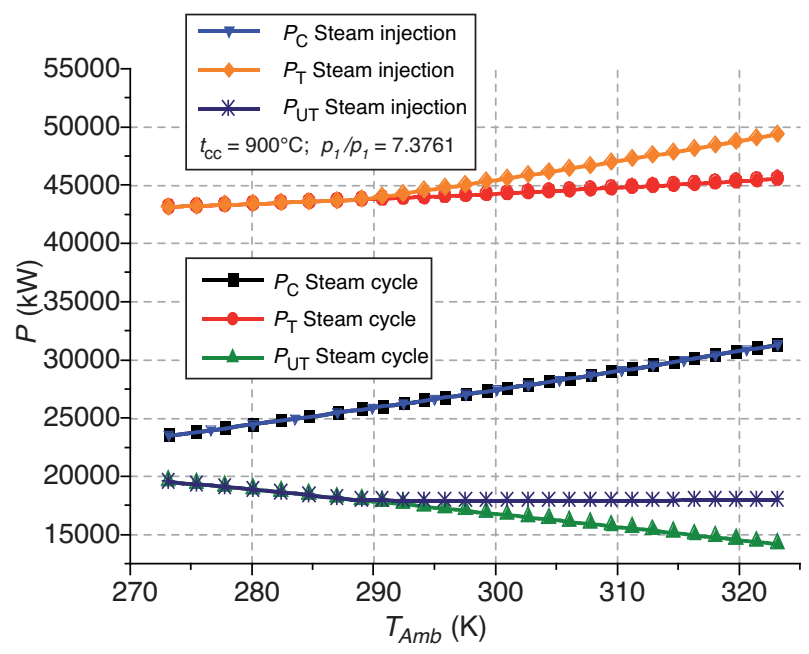

Figure 8

Powers without and with steam Injection.

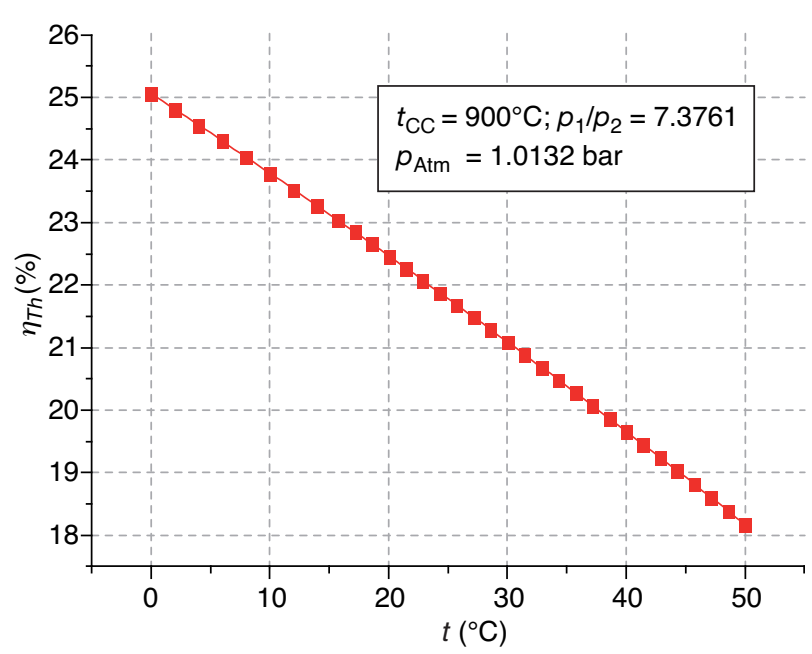

Figure 7

Thermal efficiency $v s$ ambiant temperature at fixed pressure ratio.

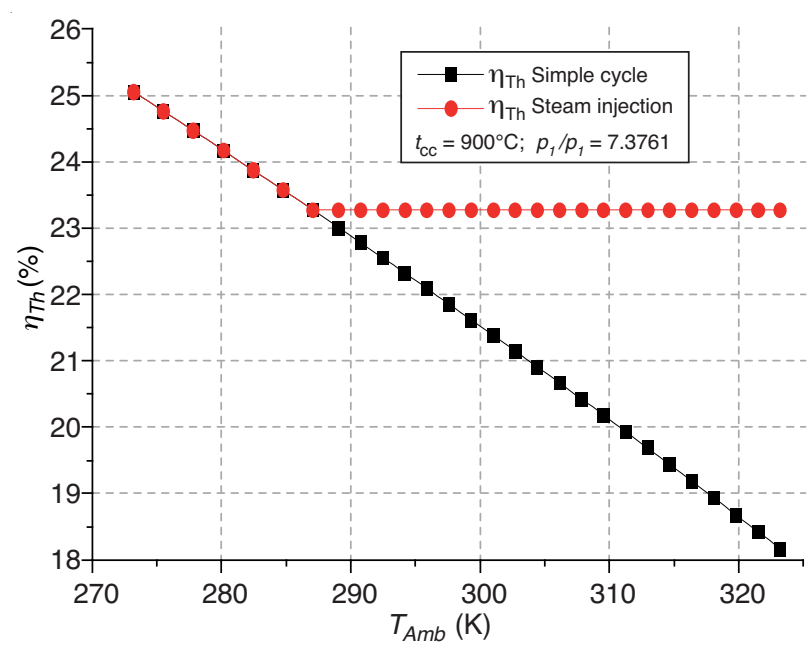

Figure 9

Efficiency without and with steam injection. rather low pressure ratio $(\varepsilon \approx 7.3671)$ and then decreases as the pressure ratio increases further. This is due of the metallurgical consideration.

Figure 7 illustrates the decrease of efficiency as function of ambient temperature for fixed value of pressure ratio. It can be seen that, with the increase of the ambient temperature, the compressor work is increased and the net power output is decreased, which will decrease the thermal efficiency.

\subsection{Gas Turbine Performances Analyzes with Steam Injection}

Figures 8 and 9 show the comparison between simple gas turbine performance and STIG cycle performance.

From Figure 8, it can be noticed that injecting steam increase the turbine power, when the ambient temperature exceeds ISO condition.

Also, it should be noted that the net power output has been kept constant by injecting steam water independent with the 
variation of ambient temperature. Same remarks have been observed for the thermal efficiency deviation (Figs. 9, 10).

This is due to the additional vapor mass injected, which thus stabilizes the net power output and so, the thermal efficiency.

Figure 11 shows the evolution of thermal efficiency, steam to air ratio versus inlet temperature. The variation of steam to air ratio is significant as the ambient temperature become higher than ISO temperature according the injection of steam (Fig. 12).

Typically, the maximum reduction of efficiency is shown nearly $15^{\circ} \mathrm{C}$. In contrast, steam may be injected with suitable amounts for performance improvement purposes. Furthermore, the gas turbine will be insensitive with the variation of ambient temperature.

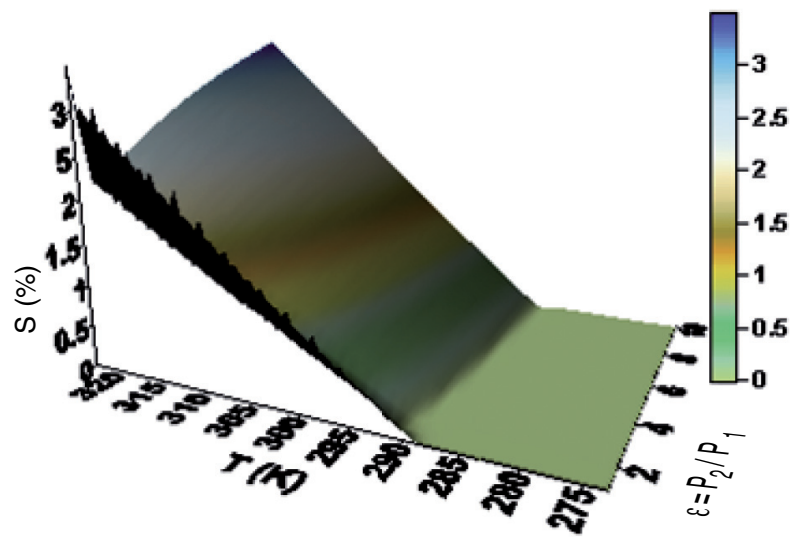

Figure 12

Steam to air ratio injected.

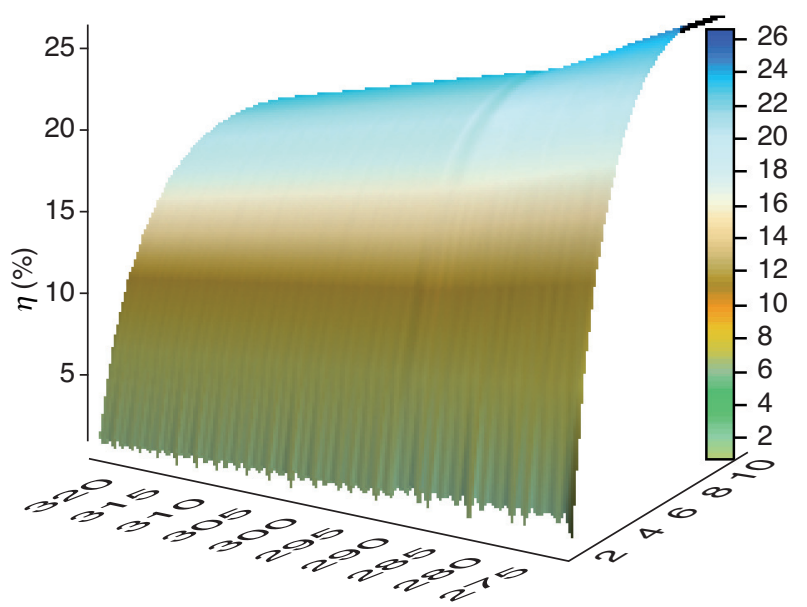

Figure 10

Total thermal efficiency.

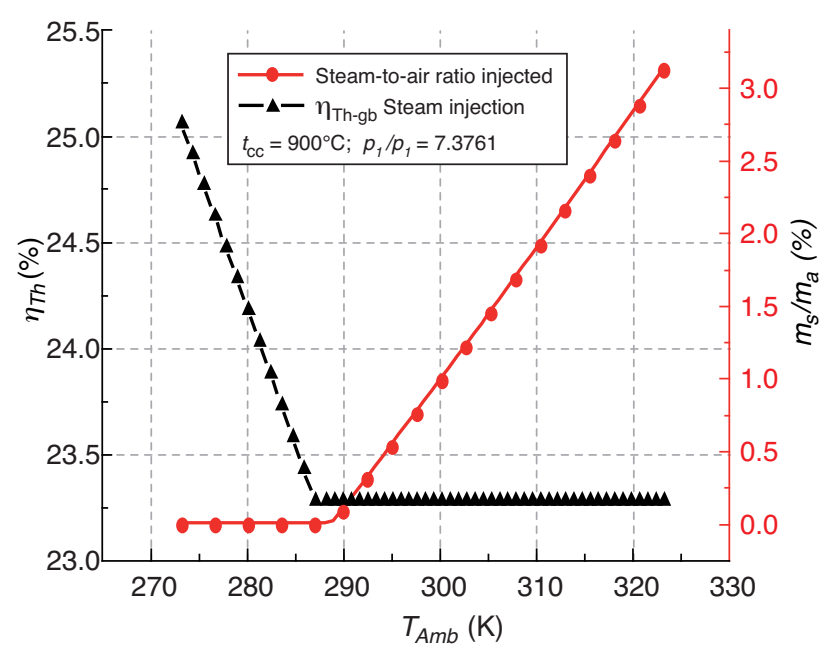

Figure 11

Efficiency and steam to air ratio injected.
Comparison of between the fluids engine in both cases: for a simple cycle and a cycle injected by vapor during an operation of the machine for the four seasons. It is obvious the mass throughput of the driving fluid increases with the injection of the suitable quantity of the steam. With this operation, it is possible to bring back the normal operation of the gas turbine under environmental conditions $\left(t_{A m b}=50^{\circ} \mathrm{C}\right)$ towards an operation to $t_{I S O}$.

\subsection{Influence of the Injection Parameters on the Injected Steam Quantity}

Wide rage of the parameters values (injection pressure and the injection temperature) of the steam injected have been taken in order to study their influence on the steam quantity injected and on the gas turbine performances.

Figures 13-16 show the evolutions respectively, according to the ambient temperature, of the turbine power, the net power output, the necessary quantity of steam injected in order to bring back the operation of this turbine to a standard temperature and the thermal efficiency of this equipment.

Figures 14, 15 show that all curves of the performances (powers and net power) changes starting from $T_{I S O}$. This latter is the beginning of improvement of the gas turbine performances.

The first parts of curves are identical (in the case without injection). In the case of steam injection:

- The amount of steam injected is increased when the inlet parameters increased

- The amount of steam injected is decreased when the parameters values (injection pressure and the injection temperature) of the steam injected increased.

In the first parts the curves are identical (in the case without injection). In the first case it is clear (there is not the steam injection), the parameters values do not intervene in calculation. In the second case (with injection) this due for 


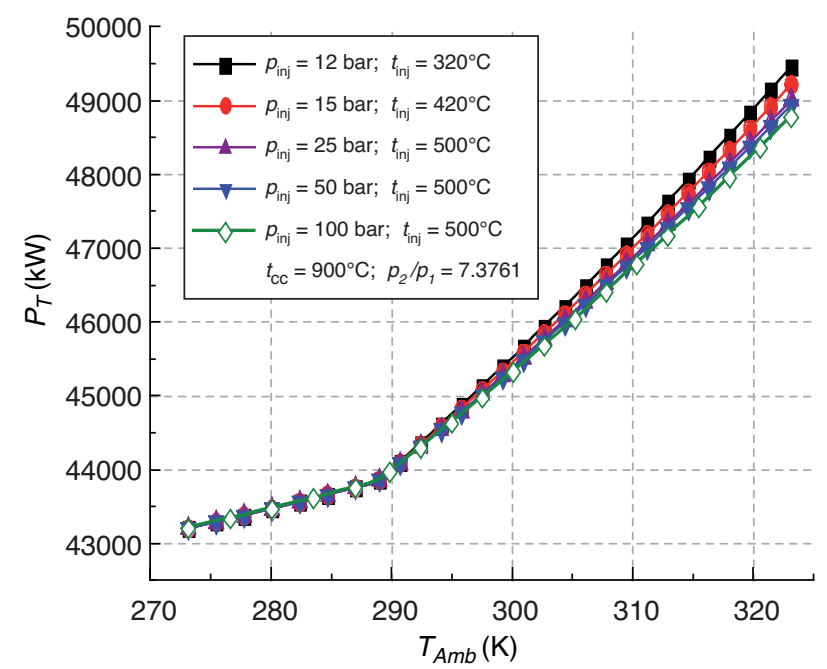

Figure 13

Turbine power.

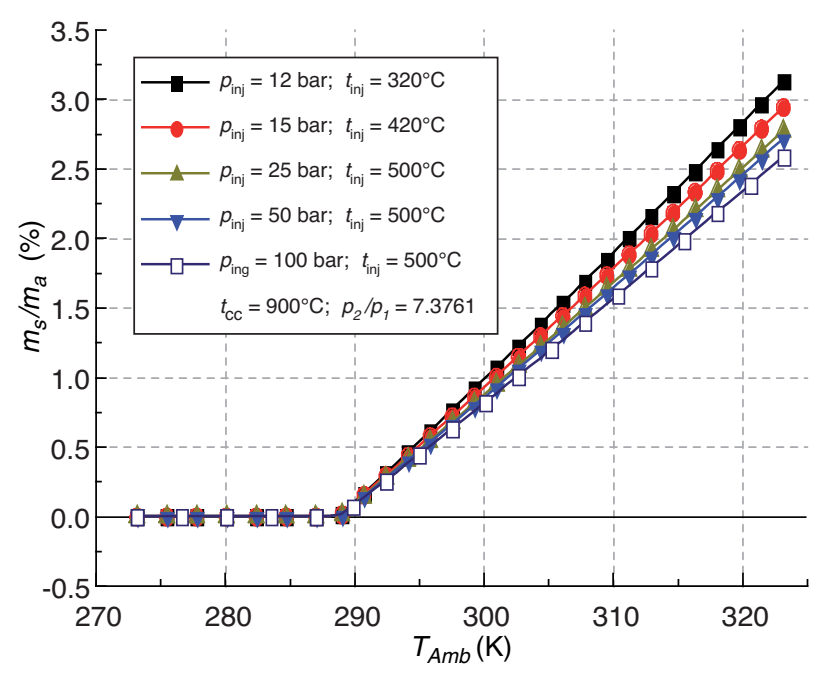

Figure 15

Steam quantity injected.

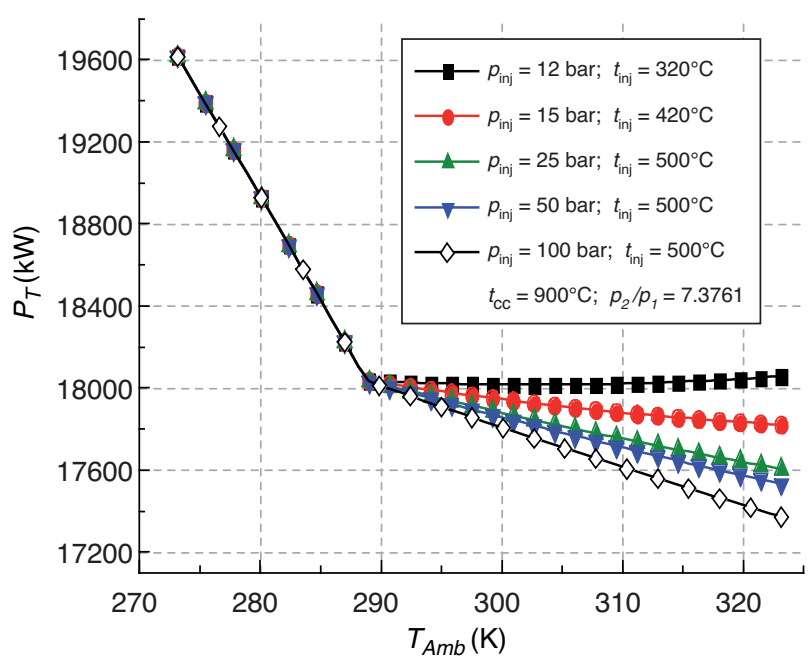

Figure 14

Net power output.

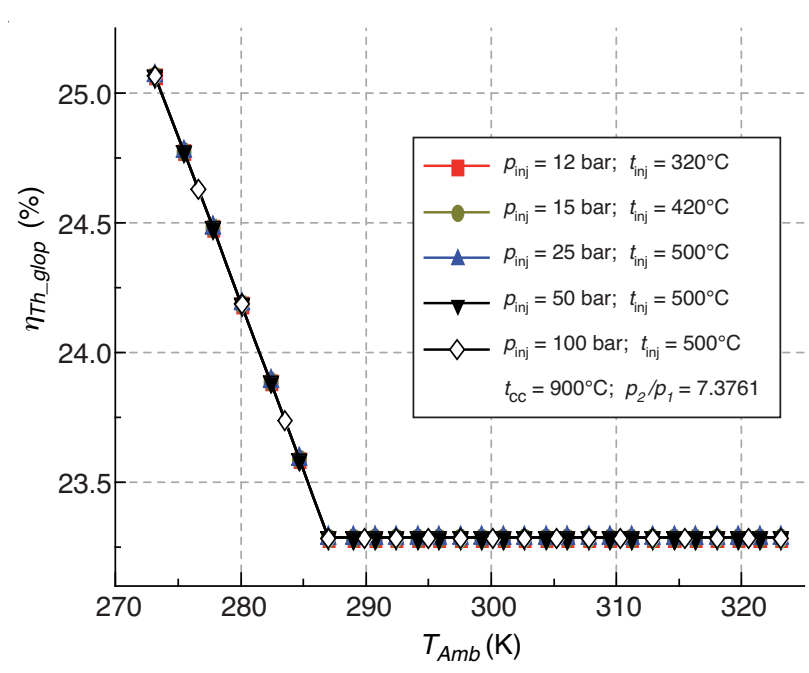

Figure 16

Efficiencies. the mixture temperature in the amount of the combustor which increased with increasing of the parameters values of steam injection.

In Figure 16, we note that thermal efficiencies does not depend on these parameters of the injection (efficiencies are identical), because the variation of these parameters influence on the quantity of the fuel to be injected.

Analysis of these figures shows that when we increase the injection steam parameter values we have a reduction in the quantity injected of steam. This is evident because when we increases the injection steam temperature we have an increase in the balance temperature of mixture; and to maintain the combustion chamber temperature constant it is necessary to decrease the quantity of the steam injected.

\subsection{Influence of Operating Ambient Temperature ( $\left.T_{I S O}\right)$}

It is interesting to visualize the displacement of the point where the injection of the steam water starts, by varying the standard operating temperature $\left(T_{I S O}\right)$ of a given step. 


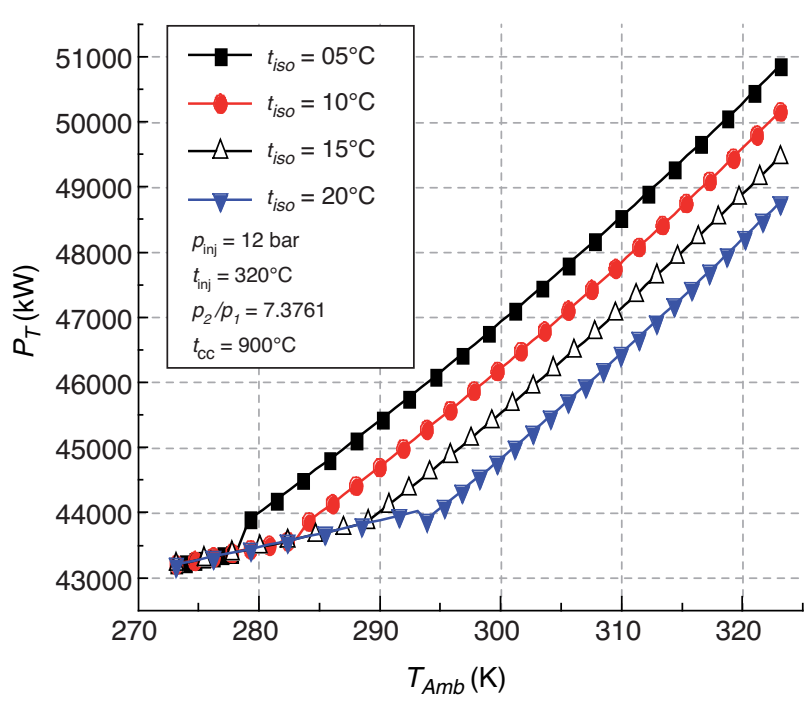

Figure 17

Turbine power.

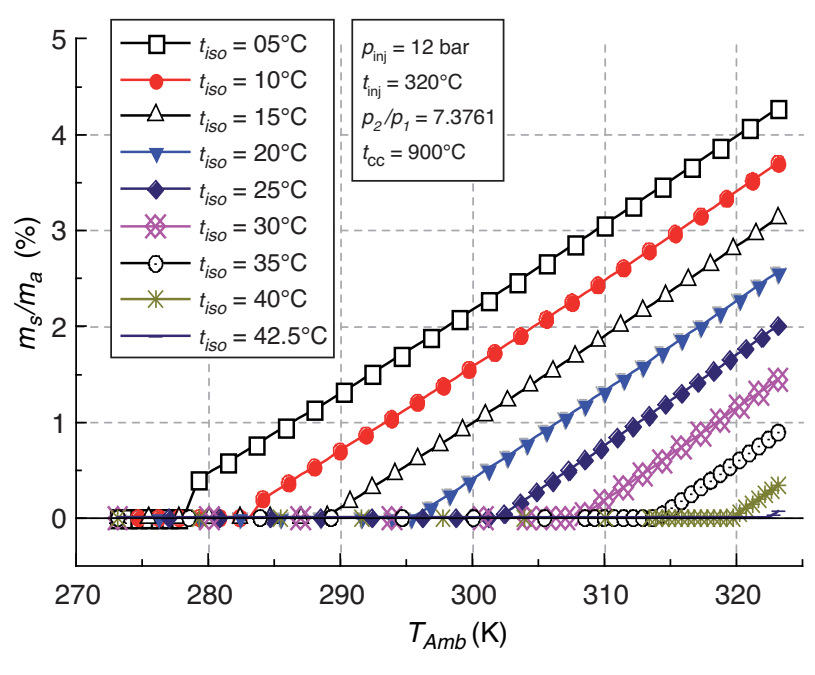

Figure 18

Steam quantity injected.
The profiles of turbine power, the necessary of steam quantity injected, net power output and the total thermal efficiency are presented respectively in Figures 17-20.

Starting the $T_{I S O}$ temperature, power of turbine and steam injected quantity profiles changes their course evolution upwards, because the power of turbine increase when the steam injection start.

We note in Figure 20 when the ambient temperature is inferior to the standard temperature $\left(T_{A m b}<T_{I S O}\right)$ the gas turbine performance decrease by increasing the ambient temperature this is due to the increasing of a compressor specific work. When the ambient temperature is higher than the standard temperature $\left(T_{A m b}>T_{I S O}\right)$, the gas turbine efficiencies remains constant with the value corresponds to $t_{I S O}$ by the suitable qantity of steam injection in the combustor. Figure 20 shows the displacement of the beginning point of an injected steam water which corresponds to $T_{I S O}$.

\section{RESULTS VALIDATION}

The results obtained by the computer model have been verified using data from the performance testing of an industrial gas turbine which the characteristics are known. A modification of the computer program treats steam injection effects on gas turbine performances. The previous literature studies modelling the thermodynamic cycles reveal that best performance are obtained for decreasing NOx emission, and, therefore, net power output by injecting steam into combustion chamber [23-31]. The study presented in this section provides that inlet conditions of com-

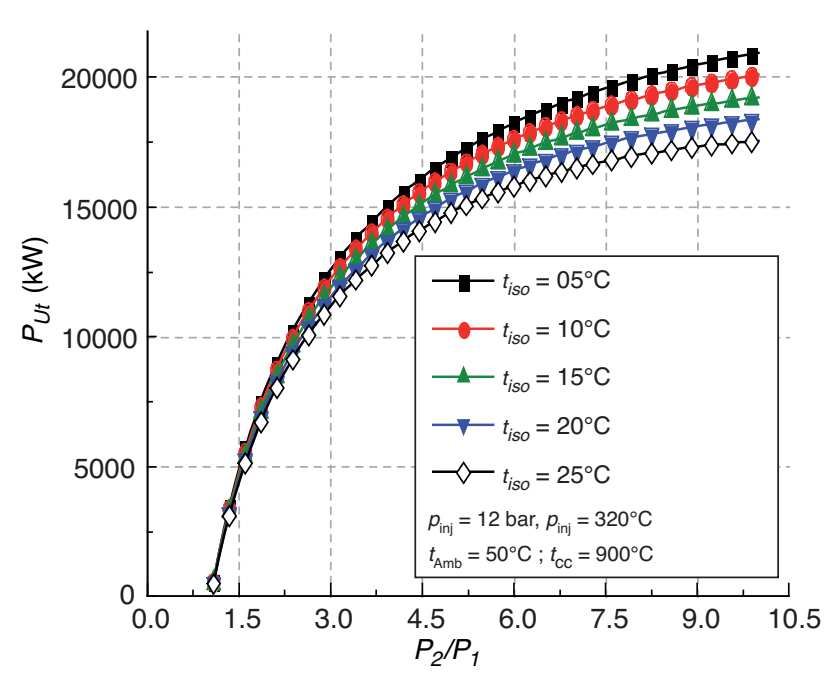

Figure 19

Net power output.

pressor are fixed at standard conditions. For wide range of steam injected quantities, the values obtained were compared with those of the literature.

\subsection{Effects of Steam Injection on the Net Power Output}

Figure 21 shows the evolution of the net power output variation as a function of steam to air ratio. Results for operation 


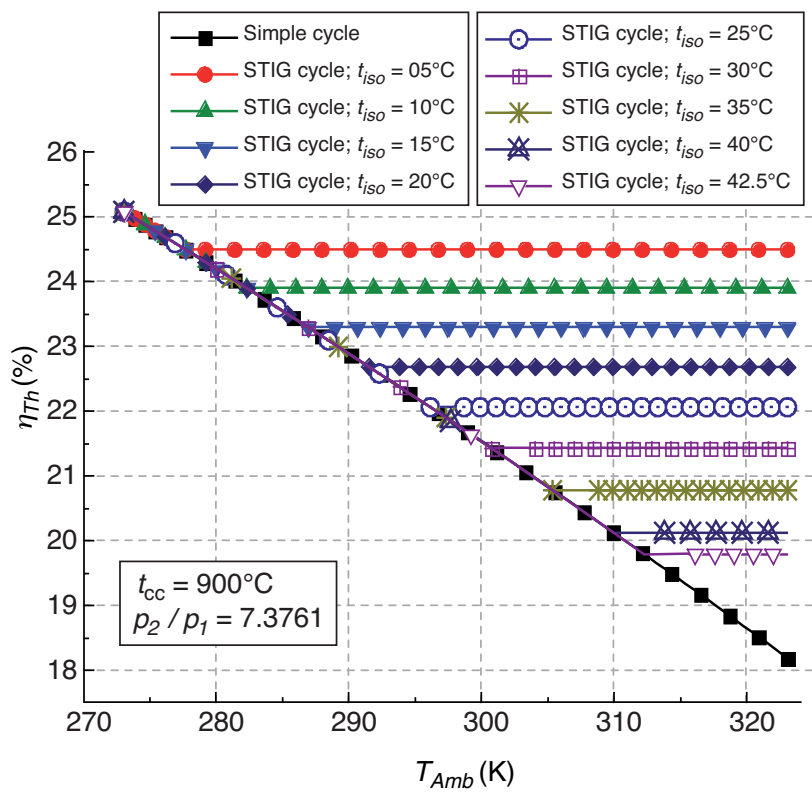

Figure 20

Efficiencies.

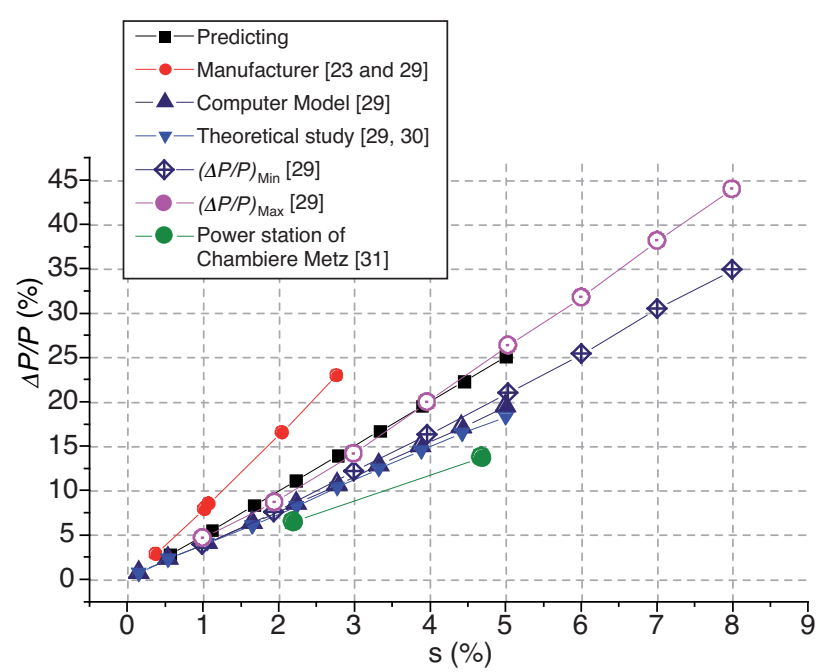

Figure 21

Net Power output deviation.

with injection of steam are shown. The lines represent the prediction using our modified computer code and points prediction of the same conditions.

It is shown that predictions with the proposed model are in very close agreement with data published in the literature. It is interesting to note that for higher steam to air ratio $(s)$, the prediction of the present method is very close to the upper limit (of a range carried out for several gas turbines) [29].

\subsection{Effects of Steam Injection on the Efficiency}

The effect of steam injection on the gas turbine efficiency is shown in Figure 22. Typically, same evolutions are observed as the above figure. We note that our computation results are in good agreement with those of the literature [23-31].

\section{CONCLUSION AND PERSPECTIVE}

The STIG cycle plant plays an important role to improve the gas turbines performances. For this purpose, detailed researches were made to study the improvement of real cycle gas turbine with and without steam injection.

Under hard climatic conditions, the gas turbines of Algerian petroleum plant were used. The ambient temperature varies considerably during the year can often reach $50^{\circ} \mathrm{C}$ in summer which reducing $28 \%$ of net power output gas turbine.

The objective of the present study is to improve the performances of gas turbine used under Sahara conditions by injecting suitable quantities of steam in the upstream of combustion chamber. The suggested method has been studied and compared with a simple cycle. Efficiency, however, is held constant when the ambient temperature increases from ISO conditions to $50^{\circ} \mathrm{C}$. Computer program has been developed for various gas turbine processes including the effect of ambient temperature. This is achieved by studying the effect of steam injection on the gas turbine performances.

Data published in the literature from the performance testing are used to verify the validity of the proposed model. It was shown that general trends exist for the current prediction by using published data.

The device installation with a feed water circuit, economizer and evaporator is proposed. The exhaust is used as an energy source in a heat recovery steam generator (HRSG)

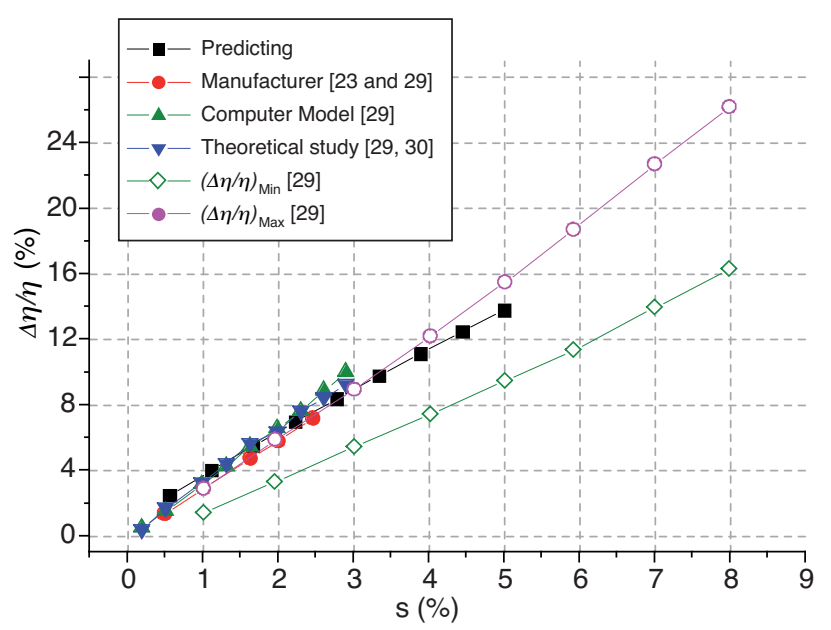

Figure 22

Thermal efficiency deviation. 
where energy is transferred from the exhaust gases to boiler feed water.

In perspective, we focused to extend our approach to predict NOx emissions.

\section{ACKNOWLEDGEMENT}

We would like to acknowledge Mr. Anis Bousbia Salah (Fabio Moretti, Francesco D'Auria Università di Pisa) for his expertise and generous help in generating this work.

\section{REFERENCES}

1 Horlock J.H. (2003) Advanced gas turbine cycles, Pergamon Press, Oxford edition.

2 Potter P.J. (1976) Power plant theory and design, 2nd edition of steam power plant, John Wiley \& sons, New York, Chichester, Brisbane, Toronto.

3 El-Wakil M.M. (1985) Power plant technology, International student edition, 1st printing.

4 Paepe M.D., Dick E. (2000) Cycle improvements to steam gas turbines, Int. J.Energ. Res. 24, 1081-1107.

5 Haselbacher H. (2005) Performance of water/steam injected gas turbine power plants consisting of standard gas turbines and turbo expanders, Int. J. Energ. Technol. Policy 3, 1, 2.

6 Cheng D.Y., Nelson A.L.C. (2002) The chronological development of the change cycle steam injected gas turbine during the past 25 years, Proceedings of ASME Turbo Expo.

7 Traverso A., Massardo A.F. (2002) Thermo-economic analysis of mixed gas-steam cycles, Appl. Therm. Eng. 22, 1-21.

8 Fraize W.E., Kinney C. (1979) Effects of steam injection on the performance of gas-turbine power cycles, ASME J. Eng. Power 101, 217-227.

9 Brown D.H., Cohn A. (1981) An evaluation of steam-injected combustion turbine systems, ASME J. Eng. Power 103, 13-19.

10 Larson E.D., Williams R.H. (1987) Steam-injected gas-turbines, ASME J. Eng. Gas-Turbines Power 109, 55-63.

11 Macchi E., Consonni S., Lozza G., Chiesa P. (1995) An assessment of the thermodynamic performance of mixed gas-steam cycles: Part A - Intercooled and steam-injected cycles, ASME J. Eng. Gas-Turbines Power 117, 489-498.

12 Rice I.G. (1995) Steam-injected gas-turbine analysis: steam rates, ASME J. Eng. Gas-Turbines Power 117, 347-353.

13 Nishida K., Takagi T., Kinoshita S. (2005) Regenerative steaminjection gas-turbine systems, Appl. Energ. 81, 231-246.

14 Heppenstall T. (1998) Advanced gas turbine cycles for power generation: a critical review, Appl. Therm. Eng. 18, 837-846.

15 Ohno Y., Zhao D., Furuhata T., Yamashita H., Arai N., Hisazumi Y. (2001) Combustion characteristics and NOx formation of a gas turbine system with steam injection and two-stage combustion, Proceedings of 2000 International Joint Power Generation
Conference \& Exposition, Miami Beach, Florida, July 23-26, ASME paper IJPGC 2000-15046.

16 Moore M.J. (1997) Nox emission control in gas turbines for combined cycle gas turbine plant, Proc. Instn Mech Engrs 211 Part-A Imeche.

17 Zhao D., Ohno Y., Furuhata T., Yamashita H., Arai N., Hisazumi Y. (2001) Combustion technology in a novel gas turbine system with steam injection and two-stage combustion, J. Chem. Eng. Jpn 34, 9, 1159-1164.

18 Milancej M. (2005) Advanced Gas Turbine Cycles: Thermodynamic Study on the Concept of Intercooled Compression Process, Diploma Thesis, Institut für Thermodynamik und Energie wandlung Technische Universität Wien Vienna.

19 Feidt M., Costea M., Postelnicu V. (2006) Comparaison entre le cycle simple de Brayton avec apport thermique imposé et avec contrainte de température maximale, Oil Gas Sci.Technol. 61, 2, 237-245

20 Guillet R. (2006) Du diagramme hydrométrique de combustion aux pompes à vapeur d'eau. Livre sur un nouveau regard sur la combustion et ses applications énergétiques, Elsevier, Science Ltd.

21 Kling R. (1980) Thermodynamique générale et applications, Editions Technip, Paris.

22 Keenan J.H., Chao J., Kaye J. (1979) Gas tables thermodynamic properties of air products of combustion and component gases compressible flow functions, 2nd ed., John Wiley, New York.

23 Cloyd S.T., Harris A.J. (1995) Gas turbine performance - New application and test correction curves, ASME paper 95-GT-167.

24 Porchakov B.P., Aïssani S., Mikaelian E. (1981) Essais d'une turbine à gaz avec variations de pertes de charge locales à la sortie, Rev. Générale Thermique, France 231.

25 Sonntag R.E., Borgnakke C., VanWylen G.J. (1998) Fundamentals of Engineering thermodynamics, 5th ed., John Wiley and sons, New York.

26 Goldammer H.D. (1984) Computes thermophysical Properties of water/steam, based on rational formulation for the free energy $F$ $=U-T * S$ (Helmholtz-Function), Program written and developed by Horet D., Goldammer B.T.W.B., Last Update 30. 04. 1984, Schwaebisch Gmuend, Germany.

27 International Association for the Properties of Water and Steam (1997) Release on the IAPWS Industrial Formulation 1997 for the Thermodynamic Properties of Water and Steam, Erlangen, Germany.

28 Jebaraj S., Iniyan S. (2004) A review of energy models, Renew. Sust. Energ. Rev. 1-31.

29 Mathioudakis K. (2002) Evaluation of steam and water injection effects on gas turbine operation using explicit analytical relations, Proc Instn Mech Engrs 216 Part A: J. Power Energ.

30 Poullikkas A. (2005) An overview of current and future sustainable gas turbine technologies, Renew. Sust. Energ. Rev. 9, 409-443.

31 Boissenin Y., Moliere M., Remy P. (1994) Les atouts de la turbine à gaz MS6001 B en cogénération - exemple de l'usine d'électricité de Metz, Rev. Technique Gec. Alsthom 15.

Final manuscript received in May 2007 or distributed for profit or commercial advantage and that copies bear this notice and the full citation on the first page. Copyrights for components of this work owned by others than IFP must be honored. Abstracting with credit is permitted. To copy otherwise, to republish, to post on servers, or to redistribute to lists, requires prior specific permission and/or a fee: Request permission from Documentation, Institut français du pétrole, fax. +33147527078 , or revueogst@ifp.fr. 